\title{
Time of metamitron application and concentration in the chemical thinning of 'Maciel' peach
}

\author{
Roseli de Mello Farias ${ }^{1}$, Carlos Roberto Martins², Caroline Farias Barreto ${ }^{3}$, Marcos Antônio Giovanaz ${ }^{4}$, \\ Marcelo Barbosa Malgarim5, Paulo Mello-Farias ${ }^{5}$
}

Abstract - In the peach tree cultivation, the producer has the challenge of obtaining good quality fruits and maintaining production in a balanced way over the years. Thinning favors these parameters and reduces the fruit load on plants. Manual thinning commonly practiced on peach trees requires high labor and increases production costs. Chemical thinning as an alternative to manual thinning, which depending on the species, time and concentration, has demonstrated high efficiency. The aim of this study was to evaluate the effect of metamitron applied at different seasons and concentrations on the chemical thinning of peach trees in southern Brazil. Experiments were conducted in a commercial peach orchard ('Maciel' cultivar), in the municipality of Morro Redondo, Rio Grande do Sul, Brazil, during the 2015 and 2016 harvests. In experiment 1, metamitron at concentration of $200 \mathrm{mg} \mathrm{L}^{-1}$ was applied at 20,30, 40, 50 and 60 days after full bloom and manual thinning performed at 40 days after full bloom. In experiment 2, metamitron was applied at concentrations of $100 \mathrm{mg} \mathrm{L}^{-1}, 200 \mathrm{mg} \mathrm{L}^{-1}$, $300 \mathrm{mg} \mathrm{L}^{-1}$ and $400 \mathrm{mg} \mathrm{L}^{-1}$ and manual thinning at 40 days after full bloom, in addition to control plants. Fruit abscission, fruit set, total number of fruits per plant, yield per plant, average mass and fruit diameter were evaluated. Metamitron at concentration of $200 \mathrm{mg} \mathrm{L}^{-1}$ has thinning effect when applied before 40 days after full bloom. Metamitron concentration of $100 \mathrm{mg} \mathrm{L}^{-1}$ applied at 40 DAFB promoted fruit abscission superior to manual thinning. Therefore, the application of metamitron to 'Maciel' peach trees close to full bloom at concentration of $100 \mathrm{mg} \mathrm{L}^{-1}$ results in thinning practice similar to manual thinning.

Index terms: fruit establishment, stone fruits, fruit abscission, fruit set.

Corresponding author: roseli-farias@uergs.edu.br

Received: January 31, 2019 Accepted: June 13, 2019

Copyright: All the contents of this journal, except where otherwise noted, is licensed under a Creative Commons Attribution License.

\section{(cc) $\mathbf{E Y}$}

\section{Época e concentração do metamitron no raleio químico de pessegueiro 'Maciel'}

\begin{abstract}
Resumo - No cultivo de pessegueiros o produtor tem o desafio de obter frutos de boa qualidade e manter a produção de forma equilibrada ao longo dos anos. O raleio favorece esses parâmetros e reduz a carga de frutos nas plantas. O raleio manual praticado comumente em pessegueiros, exige elevada mão de obra e onera os custos de produção. Estudos apontam o raleio químico como uma alternativa ao raleio manual, que dependendo da espécie, época e da dosagem empregada vem demonstrando eficiência nas frutíferas. O objetivo deste estudo foi avaliar o efeito do metamitron aplicado em diferentes épocas e concentrações no raleio químico de pessegueiros no Sul do Brasil. Experimentos foram conduzidos em pomar comercial de pessegueiro da cultivar Maciel, no município de Morro Redondo, Rio Grande do Sul, Brasil, durante as safras 2015 e 2016. No experimento 1 aplicou-se metamitron na concentração de $200 \mathrm{mg} \mathrm{L}^{-1}$ aos 20, 30, 40, 50 e 60 dias após a plena floração e raleio manual realizado aos 40 dias após a plena floração. No experimento 2 foram aplicados os tratamentos com metamitron nas concentrações de $100 \mathrm{mg} \mathrm{L}^{-1}, 200 \mathrm{mg} \mathrm{L}^{-1}, 300 \mathrm{mg} \mathrm{L}^{-1} \mathrm{e} 400 \mathrm{mg} \mathrm{L}^{-1}$ e raleio manual realizados aos 40 dias após a plena floração, além das plantas testemunhas. Avaliou-se a abscisão dos frutos, frutificação efetiva, número total de frutos por planta, produção por planta, massa média e o diâmetro dos frutos. O metamitron na concentração de $200 \mathrm{mg} \mathrm{L}^{-1}$ possui efeito raleante quando aplicado antes dos 40 dias após a plena floração. A aplicação de $100 \mathrm{mg} \mathrm{L}^{-1}$ de metamitron aplicado 40 DAPF promoveu a abscisão de frutos superior ao raleio manual. Portanto, a aplicação de metamitron em pessegueiros 'Maciel' mais próximo da plena floração, na concentração de $100 \mathrm{mg} \mathrm{L}^{-1}$ resulta numa pratica eficiente de raleio semelhante ao raleio manual.
\end{abstract}

Termos para indexação: pegamento de fruto, frutíferas de caroço, abscisão de frutos, frutificação efetiva.

\footnotetext{
${ }^{1}$ Agronomist, Dr., professor, Universidade Estadual do Rio Grande do Sul (UERGS), São Borja-RS, Brasil. E-mail: roseli-farias@uergs.edu.br ${ }^{\text {(ORCID }}$ 0000-0002-6265-6545)

${ }^{2}$ Agronomist, Dr., Researcher, Embrapa Clima Temperado (EMBRAPA), Pelotas-RS, Brasil. E-mail:carlos.r.martins@embrapa.br ${ }^{(0 R C I D}$ 0000-00018833-1629)

${ }^{3}$ Agronomist, M. S., Universidade Federal de Pelotas (UFPEL), Pelotas-RS, Brasil, E-mail: carol fariasb@hotmail.com ${ }^{(0 R C I D}$ 0000-0002-5568-5305)

${ }^{4}$ Agronomist, Dr., Universidade Federal de Pelotas (UFPEL), Pelotas-RS, Brasil, E-mail:ovanazmarcos@gmail.com (ORCID 0000-0001-5300-0344)

${ }^{5}$ Agronomist, Dr., Professor, Universidade Federal de Pelotas (UFPEL), Pelotas-RS, Brasil, E-mail: malgarim@ufpel.edu.br (ORCID 0000-00023584-5228); mellofarias@yahoo.com.br (ORCID 0000-0002-6519-4972)
} 


\section{Introduction}

Peach tree is one of the temperate climate fruit trees with high effective fruiting. Fruit set is determined by the relationship between number of fixed / formed fruits and number of open flowers in flowering (TOMAZ et al., 2010). High fruit set leads to the fixation of fruits higher than the ideal plant capacity, requiring the removal of part of fruits to reach commercial size and to avoid production alternation. The adoption of growth regulators in fruit production is a technological strategy that increases the technical efficiency in orchard management aiming at increasing productivity, improving fruit quality and productive efficiency (PETRI et al., 2016a).

Thinning is an indispensable practice in the management of peach trees, which has as main aim of reducing the number of fruits per plant. This practice aims to reduce the plant load so that a balance between the amount of leaves and fruits can occur in order to provide fruits of better size, flavor and color (COSTA et al., 2013, GREENE and COSTA, 2013). In all peach-producing regions, thinning is manually performed 40 to 50 days after full bloom (MEITEI et al., 2013, OLIVEIRA et al., 2017). This is the adequate occasion for the benefits of thinning, regarding competition among fruits for carbohydrates, not interfering in the cell division activity, adjusting fruit growth to their load in the plant. However, this is a labor-consuming and intensive operation, which represents a considerable increase in production costs (NACHTIGAL and KERSTEN, 2008), reaching values up to one-third of total production costs (PETRI et al. 2016a). In addition, the difficulty of finding skilled labor to carry out activities in fruit orchards has been verified in different Brazilian regions, as is the case of the region of Pelotas, the country's main peach producer intended for industry, which is responsible for more than $90 \%$ of fruit production for this purpose (FACHINELLO et al., 2011, PENSO et al., 2017).

New studies have searched for alternative chemical and mechanical thinning methods. Chemical thinning has shown to be a quick practice that reduces labor costs when compared to manual thinning (COSTA et al., 2016). Chemical thinning consists of the application of chemicals during flowering or shortly afterwards, causing the abscission of flowers and / or fruits, reducing or eliminating the manual thinning activity (PAVANELLO and AYUB, 2012). According to Petri el al. (2016a), caustic substances such as vegetable oil, lime sulfur, urea, hydrogen cyanamide and other sulfur compounds are commonly used to reduce fruit load. However, these products may harm and heavily interfere in pollination and fertilization and lead to the appearance of disturbances in fruit epidermis (OSBORNE et al., 2006). Hormonal substances have been the subject of research interest in the chemical thinning of fruits, mainly due to their greater selectivity, causing flower and fruit abscission with less development capacity, such as products based on naphthalene acetic acid, carbaryl, ethephon, benzyladenine, gibberellic acid, abscisic acid and metamitron (PETRI et al., 2016a).

Metamitron is among the products currently being tested for the chemical thinning of temperate fruit trees (McARTNEY and OBERMILLER, 2012; McARTNEY et al., 2012; McARTNEY and OBERMILLER, 2014; PETRI et al., 2016b; GOULART et al., 2017; GABARDO et al., 2017a). This product has been used for the thinning of apple trees in the Southern region of Brazil and has shown satisfactory results in the reduction of fruit load in plants (PETRI et al., 2016b; GABARDO et al., 2017a). Metamitron acts on photosystem II inhibiting electron transport (BASAK, 2011; STERN, 2014), with reducing effect on fruit quantity, possibly due to its direct action on photosynthesis inhibition (SEZERINO et al., 2015), that is, photosynthetic inefficiency reduces the production of carbohydrates required for fruit fixation. There is also the possibility that the effect is a consequence of the inhibition of electron transport, with increase in the amount of reactive oxygen species (ROS) and activation of the enzymatic system responsible for reducing the oxidative stress that triggers the abscisic acid production. However, the success of this practice depends on the genetic characteristics of the cultivar, the concentration used and the appropriate phenological moment of application (BRUNNER, 2014; McARTNEY and OBERMILLER, 2014). McArtney et al. (2012) carried out a study in peach trees with the application of metamitrom at concentrations from 100 to $400 \mathrm{mg} \mathrm{L}^{-1}$ and did not find satisfactory results for chemical thinning.

In stone fruits, Dardick et al. (2010) showed that shortly before fruit growth deceleration, there is high expression of genes responsible for lignin production. The expression of the flavonoid biosynthesis genes of pulp and epidermis appears to occur at the same time as the onset of lignification, but decreased before stone hardening. The energy resources seem to be carefully divided to allow flavonoid accumulation before stone hardening depletes the energy required. In this way, there may be a deficit of carbohydrates by the plant at the moment when the peach fruit begins lignin production for stone hardening. Fructose, glucose and sucrose are the main carbohydrates in peach fruits. High hexose concentrations have been reported during phase I of fruit growth, when there is high energy demand for cell division (MORANDI et al., 2008).

According to Raseira et al. (2014), 'Maciel' cultivar is characterized by fruit productivity and quality, and adapts to regions where winter cold is between 200 and 300 hours, with fruits of round-conical shape, large size, firm and yellow pulp. In general, anthesis occurs before budding. However, in some years, due to climatic changes, flowering may occur in the same period in which the first signs of budding of vegetative buds occur, or even 
later.

In view of the need to guarantee thinning efficiency, together with the demand for time and labor reduction, new alternatives have been proposed in new studies aiming at meeting the marketing requirements and, especially, to guarantee maintenance of peach production. In this context, the aim of this study was to evaluate the effect of metamitron as chemical thinner applied at different seasons and concentrations in 'Maciel' peach trees cultivated in southern Brazil.

\section{Material and methods}

Experiments were carried out in a commercial orchard during the years 2015 and 2016, in 'Maciel' peach trees grafted on 'Capdeboscq' in the municipality of Morro Redondo (31 32 '40.9 'S and 52 34 '42.42”W), state of Rio Grande do Sul. The orchard was implanted in the year 2006, with plants conducted in a pot system and spacing between rows of 5 meters and between plants of 2 meters, totaling density of 1000 plants ha ${ }^{-1}$.

In experiment 1 , metamitron at concentration of $200 \mathrm{mg} \mathrm{L}^{-1}$ was applied at 20,30, 40, 50 and 60 days after full bloom (DAFB) and manual thinning was performed at 40 DAFB.

In experiment 2 , chemical thinning with metamitron at concentrations of $100 \mathrm{mg} \mathrm{L}^{-1}, 200 \mathrm{mg} \mathrm{L}^{-1}, 300 \mathrm{mg} \mathrm{L}^{-1}$ and $400 \mathrm{mg} \mathrm{L}^{-1}$ and manual thinning were performed at $40 \mathrm{DAFB}$, in addition to control plants .

In both experiments, for manual thinning, a distance of 10 to $15 \mathrm{~cm}$ between fruits in the branches of peach trees, on average, was left. In treatments with chemical thinning, manual thinning was not performed. Cultural treatments such as fertilization, pruning, phytosanitary treatments and control of spontaneous plants were carried out according to recommendations for the crop (FACHINELLO et al., 2005).

Metamitron applications at different times and concentrations were carried out by spraying, using Jacto costal sprayer (40psi working pressure). The volume limit applied was the pour point, totaling on average $1000 \mathrm{~L}$ $\mathrm{ha}^{-1}$ of mixture. In order to carry out the applications of products, solutions were prepared in the field at the time of use. As source of metamitron containing $70 \%$ of active ingredient and in all treatments, $0.05 \%$ of nonionic adhesive spreader were added.

At each application time, 20 fruits per plant were measured to determine the mean fruit diameter using a digital caliper (Figure 1). To monitor the period of lignin deposition in the endocarp, the 20 fruits were cut in half and placed in phloroglucinol solution $[1 \%(\mathrm{w}$ / v) phloroglucinol, $12 \% \mathrm{HCl}(\mathrm{v} / \mathrm{v})$ and $85 \%$ ethanol $(\mathrm{v} / \mathrm{v})$ ] for one hour, according to method described by CALLAHAN et al. (2009). Fruits were washed in 95\% ethanol (v/v) for evaluation (Figure 1).
Fruit abscission (\%) was evaluated, where six previously selected branches were marked in each peach tree, counting the number of fruits before treatments and at the time of harvest. Fruit set (\%) was evaluated in the six branches marked by plant where the number of flowers in full bloom and the number of fruits at the time of harvest were counted. The number of fruits per plant (fruits plant ${ }^{-1}$ ) and production per plant $\left(\mathrm{kg}\right.$ plant $\left.^{-1}\right)$ were measured by counting and weighing fruits at the time of harvest.

Harvest was carried out in a single session on December 10, 2015 (131 DAFB) and December 14, 2016 (144 DAFB). After harvesting, a sample of 50 fruits per replicate was used for the evaluation of average fruit mass determined by weighing fruits on a digital scale and results expressed in grams (g); fruit size, classified into four diameter categories: greater than $65 \mathrm{~mm}, 65-60$ $\mathrm{mm}, 60-55 \mathrm{~mm}$ and less than $55 \mathrm{~mm}$, according to scale adapted from Oliveira et al. (2017).

The experimental design was randomized block with five replicates, each plant being an experimental unit of one plant and each year analyzed independently. Data from experiment 1 were submitted to analysis of variance using the F-Test, and averages were compared by the Scott-Knott's test at $p \leq 0.05$. In Experiment 2, when F-Test was significant for metamitron concentrations, polynomial regression was used.

\section{Results and discussion}

\section{Meteorological conditions}

The environmental conditions recorded during the peach cycle were collected from the 'Embrapa Clima Temperado' weather station at 'Cascata' experimental station, located in the municipality of Pelotas, RS, Brazil. In the year 2015, 219 hours of cold were recorded and in the year 2016 were 348 hours of cold were recorded, calculated based on temperatures below or equal to $7.2^{\circ} \mathrm{C}$. Monthly rainfall in the months from January to December in 2015 were $199.8 \mathrm{~mm} ; 85 \mathrm{~mm} ; 71.3 \mathrm{~mm} ; 49.2 \mathrm{~mm}$; $199.4 \mathrm{~mm} ; 151.8 \mathrm{~mm} ; 217.3 \mathrm{~mm} ; 102.6 \mathrm{~mm} ; 277 \mathrm{~mm}$; $266.7 \mathrm{~mm} ; 176.9 \mathrm{~mm}$ and $203.3 \mathrm{~mm}$, whereas in the year 2016, monthly rainfall from January to December were $174.7 \mathrm{~mm} ; 126.6 \mathrm{~mm} ; 275.3 \mathrm{~mm} ; 302 \mathrm{~mm} ; 117.47 \mathrm{~mm}$; $28.63 \mathrm{~mm} ; 137.35 \mathrm{~mm} ; 277.96 \mathrm{~mm} ; 181.78 \mathrm{~mm} ; 178.54 \mathrm{~mm}$; $177.47 \mathrm{~mm}$ and $186.6 \mathrm{~mm}$.

Full bloom (FB) in peach plants of 'Maciel' cultivar occurred on August 1 in the year 2015 and on July 23 in the year 2016.

\section{Time of metamitron application}

The use of metamitron promoted a thinning effect on peach fruits at the different times of application in both harvests. In 2015, the abscission percentage of manually thinned fruits was close to $60 \%$, similar to result obtained with metamitron application at 30, 50 and 
60 DAFB (Figure 2). Higher fruit abscission percentage was observed when metamitron was applied at 20 and 40 DAFB. In the year 2016, the highest fruit abscission was also verified when metamitron was applied at 20 and 40 DAFB, including application at 30 days DAFB (Figure 2). In this harvest, it was also observed that at 50 and 60 days DAFB, the fruit abscission percentage was below manual thinning values. In general, it was observed that metamitron application at the initial stages of fruit growth increases fruit abscission due to the fact that in these stages, lignin formation is still not present and fruits presented approximately 7 to $9 \mathrm{~mm}$ (20 DAFB) and 17 to $19 \mathrm{~mm}$ (30 DAFB) in diameter (Figure 1). According to Giovanaz et al. (2015), chemical thinning performed during lignin formation may lead to greater reduction of fruit load, probably because these plants are consuming more energy at this stage to form the endocarp. The fact that metamitron contributed to higher fruit abscission at early stages was also observed for apple fruits (PETRI et al., 2016b; GABARDO et al., 2017b).

Metamitron has direct action in photosynthesis inhibition, favoring fruit abscission (SEZERINO et al., 2015). This product acts on photosystem II, inhibiting electron transport (BASAK, 2011; STERN, 2014). Inhibition occurs by the binding of the active principle to the plastoquinone $\mathrm{QB}$ binding site on the D1 protein of photosystem II, causing the blockade of the electron transport from QA to QB (OLIVEIRA Jr., 2011), consequently interrupting $\mathrm{CO}_{2}$ fixation and ATP and $\mathrm{NADPH}_{2}$ production, which are essential elements for the production of carbohydrates, sugars and other compounds (GABARDO et al., 2017a). Possibly, interference in the production or translocation of carbohydrates acts as thinning agent in fruits, especially in those that are in the rapid growth phase, that is, during intense cell division, which process depends on high amounts of metabolic energy. This phenomenon intensifies in developing fruits by competition that occurs due to the excessive number of fruits in the plant, which contributes to fruit abscission. Metamitron application in plants reduces fruit load, possibly due to the impact on photosynthesis and / or through the partition between fruits and new buds that end up competing for reserves.

According to Petri et al. (2016a), competition among fruits for carbohydrates may decrease mitotic activity at the early development stages, compromising fruit growth even when fruit load is subsequently adjusted to recommended levels. It should be emphasized that metamitron has effect in reducing fruit load, regardless of time of application.

Fruit set of peach trees was higher in plants submitted to chemical thinning with metamitron at 20,30 and 50 DAFB in the years 2015 (Table 1). However, in the second year of evaluation, the highest fruit set of peach trees was observed only in plants submitted to chemical thinning with metamitron at 20 DAFB. Fruit set did not show a trend regarding application time. According to Nava et al., (2009), peach trees usually have high fruit set rates, with the contribution of environmental conditions such as flowering coinciding with sunny, mild and dry days. These authors also claim that inadequate climatic conditions during the flowering period can also influence fruit establishment, which in addition to temperature, rain or high relative humidity, facilitate the occurrence of diseases in flowers.

Although fruit abscission occurred at different levels, fruit production, regardless of time of metamitron application, was lower than that obtained by the use of manual thinning. In the 2015 harvest, in addition to higher production per plant, manual thinning resulted in higher fruit load per plant. It should be highlighted that in 2016, the highest average fruit mass (Table 1) and the highest percentage of fruits in diameter class $>65 \mathrm{~mm}$ were observed in manual thinning (Figure 3). Manual thinning enables selecting which fruits will be removed, eliminating diseased and defective ones, those of small size and those located close to or grouped in other fruits (PEREIRA and RASEIRA, 2014), adjusting the number of fruits to the vigor of branches and plants. Therefore, manual thinning probably resulted in adequate distribution of fruits along branches, allowing better growth compared to chemical thinning. Similar results were observed by Moyano et al. (2010) and El Boray et al. (2012), who observed lower peach production in chemically thinned plants due to the reduction in the number of fruits. According to Petri et al. (2016a), chemicals used as fruit thinners have combinatorial effects between application season, concentration and sensitivity of cultivars. The thinning of peach trees with metamitton in the different seasons influenced in one harvest the number of fruits and in the other, the average mass of fruits, resulting in lower fruit production in both harvests.

In the fruit diameter class, there were no significant differences between thinning methods in the year 2015, except for the 55-60 mm class. In this diameter class, the highest percentage of fruits from plants thinned with metamitron at 60 DAFB was verified. This classification reflects the result observed for the average fruit mass, in which no differences were observed in the weight of fruits between treatments. This result was not observed in the second year of evaluation, where it was found that treatments with metamitron at 30 and 60 DAFB resulted in higher percentage of fruits in the diameter class considered small ( $<55 \mathrm{~mm}$ ), generating fruits with low commercial value due to their size. In 2016, manual thinning resulted in larger fruits, with the highest percentage in diameter class greater than $65 \mathrm{~mm}$ (Figure 3). In this year, metamitron applications at $20 \mathrm{DAFB}(62.6 \%)$ and $40 \mathrm{DAFB}(56.6 \%)$ were those that more closely approached the percentage of fruits obtained in diameter classes of 60-65 $\mathrm{mm}$ and 
greater than $65 \mathrm{~mm}$, obtained with manual thinning $(86 \%)$. The fact that metamitron induced the production of fruits of smaller diameter can be a direct response on photosynthesis due to the residual effect of the product over time, possibly limiting the uptake of carbohydrates to fruits, leading to lower cell expansion. Although the comparison between harvests was not the purpose of this study, differences in the effect of metamitron application between years was observed, possibly due to climatic differences, mainly for fruit diameter class. In the 2015 harvest, it was observed in the monthly averages that during the flowering period, there was greater precipitation than in 2016.

\section{Metamitron dose}

In relation to experiment with different metamitron concentrations applied in peach trees, a change in fruit set in both years of evaluation was verified. Fruit set presented a response pattern according to quadratic regression that is, reaching the minimum value with approximately 300 $\mathrm{mg} \mathrm{L}^{-1}$ and $271 \mathrm{mg} \mathrm{L}^{-1}$ of metamitron in the year 2015 and 2016 , respectively. However, it was possible to verify that in the year 2015, metamitron application, regardless of concentration, obtained lower fruit set compared to manual thinning. However, in 2016, metamitron concentrations of 300 and $400 \mathrm{mg} \mathrm{L}^{-1}$ resulted in averages close to manual thinning (Table 2). According to Brunner (2014), metamitron has presented variability as a product used in the chemical thinning in apple trees, presenting different effects according to the cultivar, concentration and time of application.

Fruit abscission, in both years of evaluation, resulted in quadratic regression, where the highest fruit abscission was observed with metamitron concentrations of $331 \mathrm{mg} \mathrm{L}^{-1}$ (2015) and $212 \mathrm{mg} \mathrm{L}^{-1}$ (2016). However, treatments with different metamitron concentrations resulted in greater fruit abscission compared to manual thinning (Table 3). According to McArtney, and Obermiller (2014), metamitron may allow excessive fruit drop, requiring some care during application such as the phenological stage of plants and product concentration.

In 2015, the number of fruits was not influenced by metamitron application. However, in 2016, the increase in metamitron concentration provided a decrease in the number of fruits per plant (Table 3). Compared to plants that did not receive metamitron, at concentration of 100 $\mathrm{mg} \mathrm{L}^{-1}$, plants reduced the number of fruits by $14 \%$, while those with $400 \mathrm{mg} \mathrm{L}^{-1}$, reduced the number of fruits by $44 \%$. Manual thinning showed reduction of $18 \%$ in the number of fruits compared to non-thinned plants. These results were also verified by Greene (2014) and Gabardo et al. (2017a), where the increase in metamitron concentrations in the thinning of apple trees reduced the number of fruits per plant.

The average fruit mass varied according to metamitron concentrations only in the year 2016, showing increasing linear regression, that is, with the increase of metamitron concentrations, increase in the average fruit mass was observed. In absolute numbers, in both years of evaluation, it was observed that non-thinned plants presented lower average fruit mass. However, manual thinning provided higher average fruit mass in relation to treatments with metamitron (Table 3 ). Similar results were verified by Brunner (2014), in which high metamitron concentrations increased the average mass of apple fruits, reducing the number of fruits per plant.

The increase in metamitron doses provided a linear increase in fruit diameter in the year 2016. Thus, metamitron concentrations used provided larger fruits when compared to non-thinned plants. However, fruit diameter was higher in manual thinning compared to treatments with metamitron (Table 3).

Metamitron concentrations between $100 \mathrm{mg} \mathrm{L}^{-1}$ and $400 \mathrm{mg} \mathrm{L}^{-1}$ did not interfere in production per plant in both years. Although in the year 2016, plants without chemical thinning had higher number of fruits, it was not enough to significantly reflect in higher production because fruits were smaller and consequently had lower weight (Table 3 ).

The variation in the efficiency of chemical thinners between years and within the same year hinders the accuracy in the definition of the most suitable time and concentrations for their application. According to Petri et al. (2016a), both environmental and plant-related factors are involved in a complex interaction in the final response to the application of chemical thinners.

Based on results shown in Table 1, it is evident that even in treatments that promoted greater thinning effect in relation to manual thinning, the lower number of fruits was not accompanied by greater mass and yield per plant, a fact that may be associated to the residual effect of the product on the production of photoassimilates at the end of stage II and III of fruit growth. Similar result can be observed in table 3. For this, follow-up in subsequent years would be important to verify the residual effect of the product in the production of photoassimilates.

According to results found, it is necessary to study for more years the effect of metamitron concentrations on thinning, together with the monitoring of the climatic conditions in order to prospect the best time of metamitron application and concentration, depending on the climatic forecasts of each year. 
TREATMENTS

Metamitron at 20 Days after full bloom

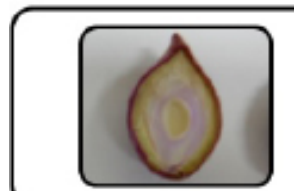

Metamitron at 30 Days after full bloom

$17-19$

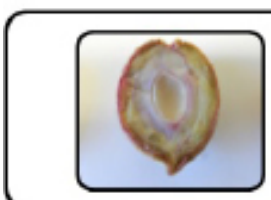

Metamitron at 40 Days after full bloom

Manual thinning

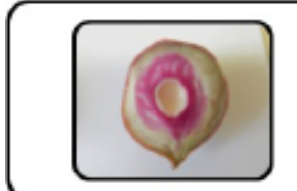

Metamitron at 50 Days after full bloom

$30-32$

Metamitron at 60 Days after full bloom

$31-33$

Figure 1- Treatments, fruit diameter and lignin formation at the time of peach tree thinning. Lignin deposition is indicated by the development of pink coloration in fruit pulp.DAFB = Days after full bloom.

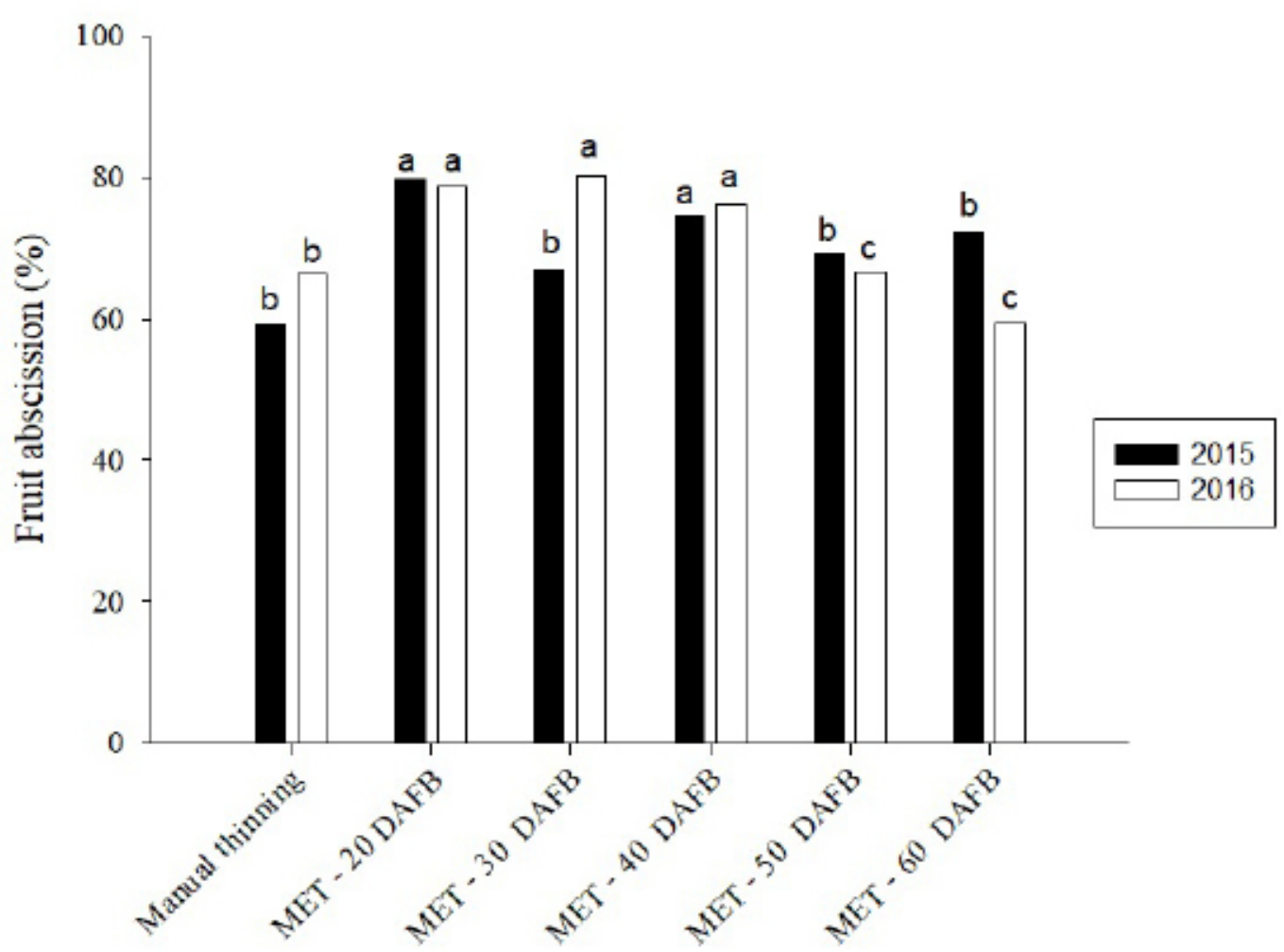

Figure 2- Abscission of 'Maciel' peach trees submitted to manual thinning and chemical thinning with metamitron at different times of application in the municipality of Morro Redondo, RS, in the 2015 and 2016 harvests. MET = metamitron. DAFB = days after full bloom. Means followed by the same lowercase letter for each evaluation year do not differ from each other by the Scott-Knott test at 5\% error probability. 
A

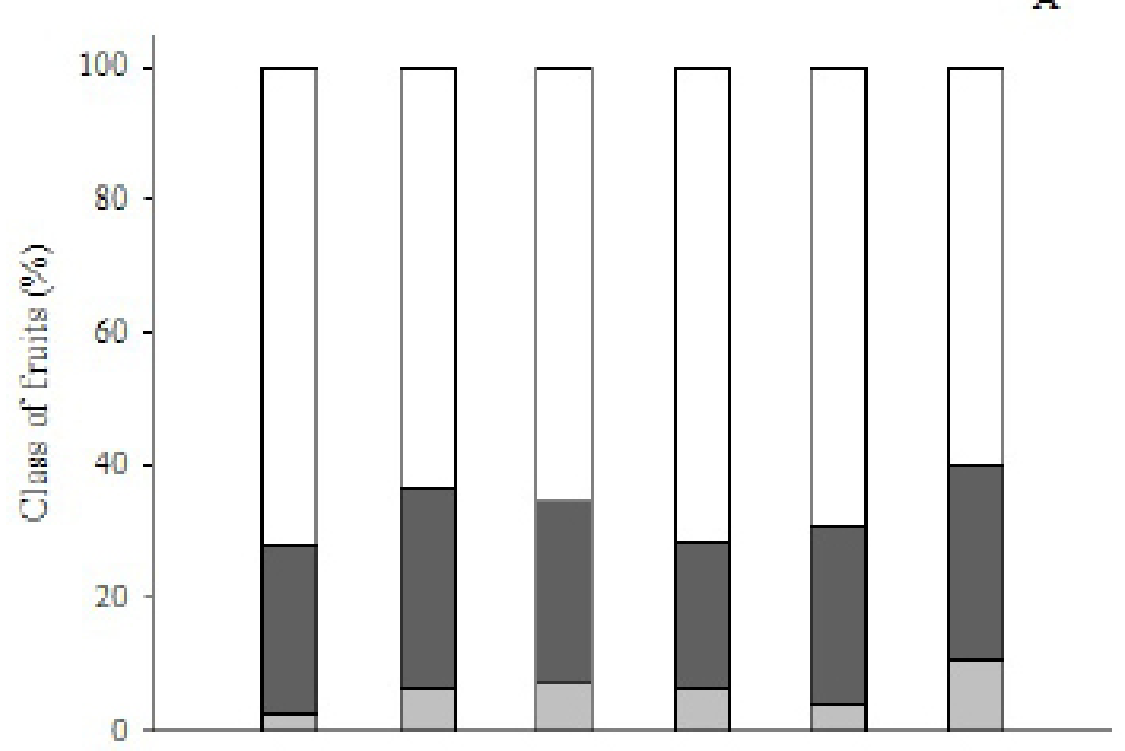

B

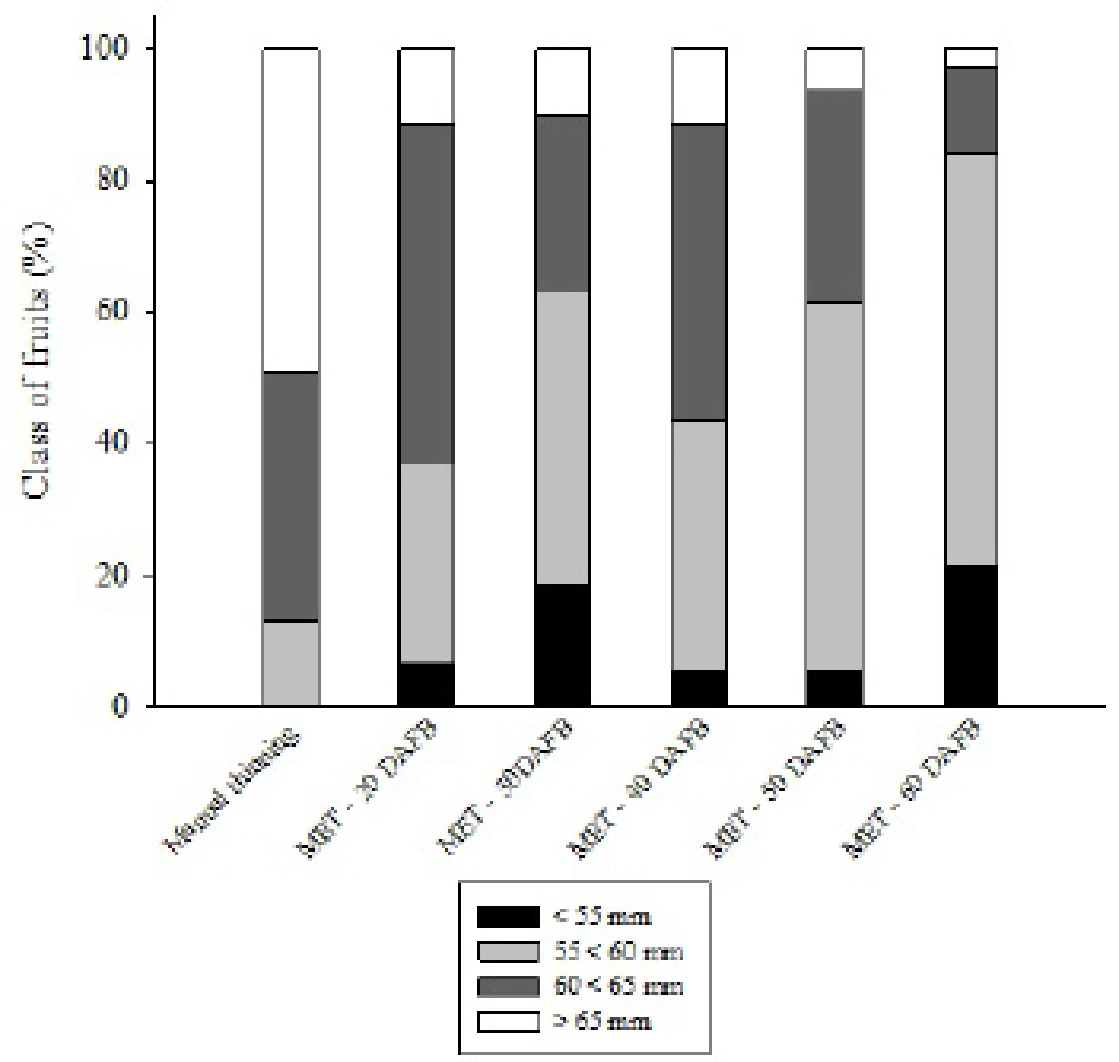

Figure 3- Diameter class of 'Maciel' peach fruits submitted to manual thinning and chemical thinning with metamitron at different application times in the municipality of Morro Redondo, RS, in the 2015 (A) and 2016 (B) harvests. MET $=$ metamitron. $\mathrm{DAFB}=$ days after full bloom. 
Table 1- Fruit Set, number of fruits per plant, average fruit mass and yield per plant of 'Maciel' peach trees submitted to manual thinning and chemical thinning with metamitron at different application times in the municipality of Morro Redondo, RS, in the 2015 and 2016 harvests.

\begin{tabular}{|c|c|c|c|c|}
\hline Treatments & $\begin{array}{l}\text { Fruit Set } \\
\quad(\%)\end{array}$ & $\begin{array}{l}\text { Average number of } \\
\text { fruits per plant }\end{array}$ & $\begin{array}{c}\text { Average } \\
\text { fresh weight of fruits }(\mathrm{g})\end{array}$ & Yield per plant $(\mathrm{kg})$ \\
\hline & \multicolumn{4}{|c|}{2015} \\
\hline Manual thinning & $13,05 \mathrm{a}$ & $304 \mathrm{a}$ & 155,96 ns & 47,41 a \\
\hline MET - 20 DAFB & 15,24 a & $234 \mathrm{~b}$ & 139,88 & $32,72 \mathrm{~b}$ \\
\hline MET - 30 DAFB & $17,77 \mathrm{a}$ & $235 \mathrm{~b}$ & 146,79 & $34,49 \mathrm{~b}$ \\
\hline MET - 40 DAFB & $10,46 \mathrm{~b}$ & $218 \mathrm{~b}$ & 149,04 & $32,49 \mathrm{~b}$ \\
\hline MET - 50 DAFB & $13,50 \mathrm{a}$ & $199 \mathrm{~b}$ & 149,74 & $29,79 b$ \\
\hline MET - 60 DAFB & $10,22 \mathrm{~b}$ & $221 \mathrm{~b}$ & 140,44 & $31,17 \mathrm{~b}$ \\
\hline \multirow[t]{2}{*}{$\mathrm{VC}(\%)$} & 26,76 & 17,91 & 11,31 & 19,90 \\
\hline & \multicolumn{4}{|c|}{2016} \\
\hline Manual thinning & $12,78 \mathrm{~b}$ & 493 ns & $126,58 \mathrm{a}$ & 62,38 a \\
\hline MET - 20 DAFB & 17,78 a & 506 & $105,00 \mathrm{~b}$ & 53,08 b \\
\hline MET - 30 DAFB & $15,75 \mathrm{~b}$ & 538 & $95,51 \mathrm{~b}$ & $51,58 \mathrm{~b}$ \\
\hline MET - 40 DAFB & $14,37 \mathrm{~b}$ & 453 & $103,60 \mathrm{~b}$ & $46,98 \mathrm{~b}$ \\
\hline MET - 50 DAFB & $12,22 \mathrm{~b}$ & 421 & 96,99 b & $40,81 \quad b$ \\
\hline MET - 60 DAFB & $14,95 \mathrm{~b}$ & 516 & 87,00 b & $44,84 \mathrm{~b}$ \\
\hline $\mathrm{VC}(\%)$ & 17,08 & 21,39 & 11,07 & 22,75 \\
\hline
\end{tabular}

Means followed by the same lowercase letter do not differ from each other by the Scott-Knott test at $5 \%$ error probability. MET $=$ metamitron. $\mathrm{DAFB}=$ days after full bloom. $\mathrm{VC}=$ Variation Coefficient. $\mathrm{ns}=$ not significant.

Table 2- Fruit set and fruit abscission peach trees submitted to manual thinning and chemical thinning with different metamitron concentrations in the municipality of Morro Redondo, RS, in the 2015 and 2016 harvests.

\begin{tabular}{ccccc}
\hline \multirow{2}{*}{$\begin{array}{c}\text { Metamitron concentrations } \\
\left(\mathrm{mg} \mathrm{L}^{-1}\right)\end{array}$} & \multicolumn{2}{c}{ Fruit set (\%) } & \multicolumn{2}{c}{ Fruit abscission (\%) } \\
\cline { 2 - 5 } & 2015 & 2016 & 2015 & 2016 \\
\hline 0 & 25,20 & 35,02 & 56,40 & 57,27 \\
100 & 7,37 & 9,45 & 82,41 & 83,49 \\
200 & 9,69 & 15,55 & 74,30 & 82,41 \\
300 & 8,44 & 12,05 & 77,19 & 78,38 \\
400 & 7,34 & 12,24 & 82,47 & 73,93 \\
\hline VC $(\%)$ & 31,3 & 25,85 & 8,62 & 6,23 \\
\hline Linear & $\mathrm{ns}$ & $\mathrm{ns}$ & $\mathrm{ns}$ & $\mathrm{ns}$ \\
Quadratic & $*(1)$ & $*(2)$ & $*(3)$ & $*(4)$ \\
\hline Manual thinning & 13,10 & 13,11 & 58,79 & 67,09 \\
\hline
\end{tabular}

(1) $\mathrm{y}=22,808-0,1201 \mathrm{x}+0,0002 \mathrm{x}^{2}\left(\mathrm{R}^{2}=0,7837\right) ;{ }^{(2)} \mathrm{y}=+31,443-0,1627 \mathrm{x}+0,0003 \mathrm{x}^{2}\left(\mathrm{R}^{2}=0,7196\right) ;{ }^{(3)} \mathrm{y}=+60,819+0,1339 \mathrm{x}-0,0002 \mathrm{x}^{2}$ $\left(\mathrm{R}^{2}=0,6214\right) ;{ }^{(4)} \mathrm{y}=60,27+0,2119 \mathrm{x}-0,0005 \mathrm{x}^{2}\left(\mathrm{R}^{2}=0,8258\right)$. ${ }^{*}$ Significant at $5 \%$ probability. $\mathrm{ns}=$ not significant. $\mathrm{VC}=\mathrm{variation}$ coefficient 
Table 3- Number of fruits, average fruit mass, mean diameter and yield per plant of 'Maciel' peach fruits submitted to manual thinning and chemical thinning with different metamitron concentrations in the municipality of Morro Redondo, RS, in the 2015 and 2016 harvests.

\begin{tabular}{|c|c|c|c|c|c|c|c|c|}
\hline \multirow{2}{*}{$\begin{array}{c}\text { Metamitron } \\
\text { concentrations } \\
\left(\mathrm{mg} \mathrm{L}^{-1}\right)\end{array}$} & \multicolumn{2}{|c|}{ Number of fruits } & \multicolumn{2}{|c|}{$\begin{array}{l}\text { Average fruit mass } \\
(\mathrm{g})\end{array}$} & \multicolumn{2}{|c|}{$\begin{array}{c}\text { Average fruit } \\
\text { diameter (mm) }\end{array}$} & \multicolumn{2}{|c|}{ Yield per plant $(\mathrm{kg})$} \\
\hline & 2015 & 2016 & 2015 & 2016 & 2015 & 2016 & 2015 & 2016 \\
\hline 0 & 323,00 & 598,25 & 144,60 & 88,71 & 64,33 & 55,15 & 46,78 & 52,58 \\
\hline 100 & 351,25 & 455,25 & 146,20 & 127,45 & 64,81 & 62,95 & 50,85 & 58,02 \\
\hline 200 & 216,00 & 424,25 & 149,70 & 102,67 & 65,13 & 58,34 & 32,02 & 43,36 \\
\hline 300 & 277,25 & 462,50 & 153,95 & 128,67 & 63,33 & 63,50 & 42,15 & 59,91 \\
\hline 400 & 266,75 & 396,00 & 155,00 & 135,02 & 65,54 & 63,66 & 41,52 & 53,16 \\
\hline $\mathrm{VC}(\%)$ & 26,34 & 27,77 & 6,67 & 12,89 & 13,91 & 4,42 & 24,58 & 26,69 \\
\hline Linear & ns & $*^{*(1)}$ & ns & $*^{*}(2)$ & ns & ${ }^{*(3)}$ & $\begin{array}{ll}\text { ns } \\
\end{array}$ & ns \\
\hline Quadratic & ns & ns & ns & ns & ns & ns & ns & ns \\
\hline Manual thinning & 305,00 & 492,75 & 164,40 & 136,54 & 66,98 & 64,02 & 49,83 & 66,93 \\
\hline
\end{tabular}

${ }^{(1)} \mathrm{y}=546,7-0,3973 \mathrm{x}\left(\mathrm{R}^{2}=0,6507\right) ;{ }^{(2)} \mathrm{y}=97,736+0,0938 \mathrm{x}\left(\mathrm{R}^{2}=0,5593\right) ;{ }^{(3)} \mathrm{y}=57,206+0,0176 \mathrm{x}\left(\mathrm{R}^{2}=0,5319\right)$. Significant at $5 \%$ probability. $\mathrm{ns}=$ not significant. $\mathrm{VC}=$ variation coefficient

\section{Conclusion}

Metamitron has thinning effect on 'Maciel' peach fruits when applied before 40 days after full bloom.

Metamitron concentration of $100 \mathrm{mg} \mathrm{L}^{-1}$ promoted fruit abscission superior to manual thinning.

The thinning effect of metamitron did not change the fruit mass and production per plant, which may be associated to the residual effect of the product on the production of photoassimilides.

\section{Acknowledgments}

To Professor José Carlos Fachinello (in memoriam) for the support and encouragement in carrying out this work. To CNPq for granting scholarships.

\section{References}

BASAK, A. Eficiency of fruitlet thinning in apple "gala must" by use of Metamitron and artificial shading. Journal of Fruit and Ornamental Plant Research, Skierniewice, v.19, n.1, p.51- 62, 2011.

BRUNNER, P. Impact of metamitron as a thinning compound on apple plants. Acta Horticulturae, The Hague, v.1042, p.173-181, 2014.

CALLAHAN, A.N.; DARDICK, C.; SCORZA, R. Characterization of 'stoneless': A naturally occurring, partially stoneless plum cultivar. Journal of the American Society for Horticultural Science, Alexandria, v.134, n.1, p.120-125, 2009.
COSTA, G.; BLANKE, M.M.; WIDMER, A. Principles of thinning in fruit tree crops - needs and novelties. Acta Horticulturae, The Hague, v.998, p.17-26, 2013.

COSTA, G.; DAL CIN, V.; RAMINA, A. Physiological, molecular and practical aspects of fruit abscission. Acta Horticulturae, The Hague, v.727, p.301-310, 2016.

DARDICK, C.D.; CALLAHAN, A.N.; CHIOZZOTTO, R.; SCHAFFER, R.J.; PIAGNANI, M.C.; SCORZA, R. Stone formation in peach fruit exhibits spatial coordination of lignin and flavonoid patways and similarity to Arabidopsis dehiscence. BMC Biology, London, v.8, p.1-17, 2010.

EL-BORAY, M.S.; SHALAN, A.M.; KHOURI, Z.M. Effect of different thinning techniques on fruit set, leaf area, yield and fruit quality parameters of Prunus persica L. Batsch cv. Floridaprince. Trends in Horticultural Research, London, v.3, n.1, p.1-13, 2012.

FACHINELLO, J.C.; PASA, M.S.; SCHMTIZ, J.D.; BETEMPS, D.L. Situação e perspectivas da fruticultura de clima temperado no Brasil. Revista Brasileira de Fruticultura, Jaboticabal, v.33, n.1, p.109-120, 2011. Número especial

FACHINELLO, J.C.; TIBOLA, C.S.; PICOLOTTO, L.; ROSSI, A. de; RUFATO, L. Produtividade e qualidade de pêssegos obtidos nos sistemas de produção integrada e convencional. Revista Brasileira de Fruticultura, Jaboticabal, v.27, n.1, p.64-67, 2005. 
GABARDO, G.C.; KRETZSCHMAR, A.A.; PETRI, J.L.; C COUTO, M.; HAWERROTH, F.J.; SILVA, C.D.S. Taxa fotossintética em macieiras tratadas com metamitron. Revista Eletrônica Científica UERGS, Bagé, v.3, n.3, p.617-633, 2017b.

GABARDO, G.C.; PETRI, J.L.; HAWERROTH, F.J.; COUTO, M.; ARGENTA, L.C.; KRETZSCHMAR, A.A. Use of metamitron as an apple thinner. Revista Brasileira de Fruticultura, Jaboticabal, v.39, n.3, e-514, 2017 a.

GIOVANAZ, M.A.; SPAGNOL, D.; BARTZ, J.; PASA, M.S.; CHAVES, F.C.; FACHINELLO, J.C. Abscisic acid as a potential chemical thinner for peach. Pesquisa Agropecuária Brasileira, Brasília, DF, v.50, n.10, p.989992, 2015.

GOULART, G.; ANDRADE, S.B.; BENDER, A.; SHIAVON, A.V.; AGUIAR, G.A.; MALGARIM, M.B. Metamitron and different plant growth regulators combinations in the chemical thinning of 'Eva' apple. Journal of Experimental Agriculture International, New Delhi, v.18, n.2, p.1-6, 2017.

GREENE, D.W. Use of metamitron alone and in combination with 6-benzyladenine for thinning APPLES. Acta Horticulturae, The Hague, v.1042, p.167-172, 2014.

GREENE, D.W.; COSTA, G. Fruit Thinning in Pome- and Stone-Fruit: State of the Art. Acta Horticulturae, The Hague, v.998, p.93-102, 2013.

MCARTNEY, S. J E OBERMILLER, J. D. Use of shading and the psii inhibitor Metamitron to investigate the relationship between carbohydrate balance and chemical thinner activity in apples, Acta Horticulturae, 1042, 2731, 2014.

MCARTNEY, S. J.; OBERMILlER, J. D. Use of 1-Aminocyclopropane Carboxylic Acid and Metamitron for Delayed Thinning of Apple Fruit. HortScience, 47, 1612-1616, 2012.

McARTNEY, S.J.; OBERMILLER, J.D.; ARELLANO, C. Comparison of the Effects of Metamitron on Chlorophyll Fluorescence and Fruit Set in Apple and Peach. HortScience, Alexandria, v.47, n.4, p.509-514, 2012.
MEITEI, S.B.; PATEL, R.K.; DEKA, B.C.; DESHMUKH, N.A.; SINGH, A. Effect of chemical thinning on yield and quality of peach cv. Flordasun. African Journal of Agricultural Research, Nairobi, v.8, n.27, p.3358-3565, 2013.

MORANDI, B.; GRAPPADELLI, L.G.; RIEGER, M.; BIANCO, R.L. Carboydrate availability effects growth and metabolism in peach fruit. Physiologia Plantarum, Lund, v.113, p.229-241, 2008.

MOYANO, M. I.; FLORES, P.; SETA, S.; LEONE, A.; SEVERIN, C. Efecto de diferentes prácticas culturales sobre la producción, calidad y maduración de frutos de duraznero cv. Early Grande. Ciencias Agronómicas, Santa Fé, n.15, p.7-11, 2010.

NACHTIGAL, J.C.; KERSTEN, E. Raleio. In: FACHINELLO, J.C.; NACHTIGAL, J.C.; KERSTEN, E. Fruticultura: fundamentos e práticas. Pelotas: UFPe, 2008. p.103-113.

NAVA, G.A.; DALMAGO, G.A.; BERGAMASCHI, H.; PANIZ, R.; DOS SANTOS, R.P.; MARODIN, G.A.B. Effect of high temperatures in the pre-blooming and blooming periods on ovule formation, pollen grains and yield of 'Granada peach. Scientia Horticulturae, Amsterdam, v. 122, p. 37-44, 2009.

OLIVEIRA JR, R.S.; CONSTANTIN, J.; INOUE, M. H. Biologia e manejo de plantas daninhas. Curitiba: Ed. Omnipax, 2011. v.1.348p.

OLIVEIRA, P.D.; MARODIN, G.A.B.; ALMEIDA, G.K.; GONZATTO, M.P.; DARDE, D.C. Heading of shoots and hand thinning of flowers and fruits on 'BRS Kampai' peach trees. Pesquisa Agropecuária Brasileira, Brasília, DF, v.52, n.11, p.1006-1016, 2017.

OSBORNE, J. L.; ROBINSON, T. L.; PARRAQUEZADA, R. Chemical blossom thinning agents reduce crop load of "Rising Star" peach in New York. Acta Horticulturae, The Hague, v.727, p.423-428, 2006.

PAVANELLO, A.P.; AYUB, R.A. Aplicação de Ethephon no raleio químico de ameixeira e seu efeito sobre a produtividade. Revista Brasileira de Fruticultura, Jaboticabal v.34, n.1, p.309-316, 2012. 
PENSO, G. A.; DOS SANTOS, C. E. M.; BRUCKNER, C. H.; DA COSTA, J. C. F. CITADIN, I. Consumption, preferences and habits of purchasing consumers of peaches and nectarines. Revista Brasileria de Fruticultura. Jaboticabal v.40, n.3, e-497, 2018. Disponível em: $<\underline{\text { http:// }}$ dx.doi.org/10.1590/0100-29452018497> . Acesso em: 19 mar de 2019.

PEREIRA, J.F.M.; RASEIRA, A. Raleio. In: RASEIRA, M.C.B.; PEREIRA, J.F.M.; CARVALHO, F.L.C. (Ed.). Pessegueiro. Brasília, DF: Embrapa, 2014. p.309-327.

PETRI, J.L.; COUTO, M.; GABARDO, G.C.; FRANCESCATTO, P.; HAWERROTH, F.J. Metamitron replacing carbaryl in post bloom thinning of apple trees. Revista Brasileira de Fruticultura, Jaboticabal, v.38, e-903, $2016 b$.

PETRI, J.L.; HAWERROTH, F.J.; LEITE, G.B.; SEZERINO, A.A.; COUTO, M. Reguladores de crescimento para frutíferas de clima temperado. Florianópolis: Epagri, 2016a. 141p.

RASEIRA, M.D.B.; NAKASU, B.H.; BARBOSA, W. Cultivares: descrição e recomendação. In: RASEIRA, M.C.B; PEREIRA, J.F.M.; CARVALHO, F.L.C. (Ed.). Pessegueiro. Brasília, DF: Embrapa, 2014. p.73-141.
SEZERINO,A.A.; PETRI, J.L.; COUTO, M.; GABARDO, G.C.; ESPERANÇA, C.F. Efeito do metamitron no raleio químico de pós floração da macieira 'Fuji Suprema'. In: Encontro nacional sobre fruticultura de clima temperado, 14, 2015, Fraiburgo. Anais [...] Caçador: EPAGRI, 2015. p.4.

STERN, R.A. The photosynthesis inhibitor metamitron is na effective fruit-let thinner for 'Gala' apple in the warm climate of Israel. Scientia Horticulturae, Amsterdam, v.178, p.163-167, 2014.

STOVER, E.; FARGIONE, M.; RISIO, R.; YANG, $\mathrm{X}$.; ROBINSON, T. Fruit weight, cropload, and return bloom of 'Empire' apple apple following thinning with 6-benzyladenine and NAA at several phonological stages. HortScience, v.36, p.1077-1081, 2001.

TOMAZ, Z.F. P.; LIMA, C. S. M.; GONÇALVES, M. A.; RUFATO, L.; RUFATO, A. D. R. Crescimento vegetativo, floração e frutificação efetiva do pessegueiro 'Jubileu' submetido a diferentes comprimentos de interenxertos. Pesquisa Agropecuária Brasileira, Brasília, DF, v.45, n.9, p.973-979, 2010. 